\title{
Renk-Mekân-Anlatım İlişkisinin Sinemekânlarda İncelenmesi: Wes Anderson Filmleri
}

\author{
Tülay CANBOLAT ${ }^{1 *}$, Sabit Umut ÖNER ${ }^{2}$
}

Öz

Renkler; sahip oldukları anlam ve temsiliyet güçleriyle, mekân tasarımında anlatım dili oluşturmak için kullanılan en etkili araçlardan biridir. Renklerin anlam ve temsiliyet gücü, insanların fiziksel, psikolojik ve sosyolojik algılarına dayanmaktadır. İnsanlar üzerinde yarattığı etkiler ve uyandırdığı çağrışımlar sonucunda renklere anlam yüklenmektedir. Renklerin bu rolü sinema sanatında da kullanılmaktadır. Yönetmenler anlatım dili yaratırken renklerin kendine özgü kavramsal gücüne bir yöntem olarak başvurmaktadır. Renkleri öznel algılayış biçimine göre tasarlayarak izleyiciye sunan ve bu renklerden kendine özgü kurgusal mekânlar yaratan yönetmenlerden biri Wes Anderson'dır. Bu çalışmada amaçlanan; renk, renk algısı ve renk dili gibi kavramların kuramsal bağlamda araştırıması, renk kullanımının mekân ve anlatım diliyle olan ilişkisinin sinemekân özelinde incelenmesidir. Sinemekânsal renk incelemelerinde, Wes Anderson'ın seçilen filmleri çalışma kapsamına alınmaktadır. Bu filmlerden seçilen sinemekânların renk skalaları oluşturularak, renk-mekân-anlatım ilişkisi disiplinlerarası bir düzlemde irdelenmektedir. Çalışmanın iç mimarlık alanına katkısı, mekân atmosferi ve anatım dili oluşturmada rengin, psikolojik, resimsel, sembolik ve tarihsel verilerinin tasarımcılara ve literatüre kaynak oluşturmasıdır.

Anahtar Kelimeler: Renk, Mekân, Anlatım dili, Sinemekân, Wes Anderson

\section{An Examination of Color-Space-Narrative Relationship in Cine-Spaces: Wes Anderson Films}

\begin{abstract}
Colors are one of the most impressive tools used to create a narrative language in the design of space with their meaning and representation powers. The meaning and representation power of colors is a product of the physical, physiological and sociological perceptions of the people. As a result of their effects on people and the associations they create, colors are given meaning. This role of colors is also used in the cinema art. When creating a narrative language, directors use the unique conceptual power of colors as a method. One of the directors who present colors to the audience after designing them according to the subjective perception and create unique fictional spaces from these colors is Wes Anderson. The aim of this study is to examine the concepts such as color, color perception and color language in a theoretical context and to analyze the relationship between the use of colors and space and a narrative language in cinema-spaces. In the cine-spatial color analysis, Wes Anderson's films that selected are included in the study. The color scales of the cine-spaces selected from these films are created and the color-space-narrative relationship is studied on an interdisciplinary level. Contribution of the study to the field of interior architecture is that the colour's pyschological, pictorial, symbolic and historical data is a source for designers and literature in creating spatial mood and expression language of color.
\end{abstract}

Keywords: Color, Space, Narrative language, Cine-space, Wes Anderson

1 Dr.Öğr.Üyesi, Çukurova Üniversitesi, Mimarlık Fakültesi, İç Mimarlık Bölümü

2 Çukurova Üniversitesi, Sosyal Bilimler Enstitüsü, İç Mimarlık Anasanat Dalı, Yüksek Lisans Programı

* İlgili Yazar/Corresponding Author: ozdemir.tulay@gmail.com

Gönderim Tarihi: 19.11.2019

Kabul Tarihi: 24.12.2019 


\section{GíRiş}

Renk, insanın görsel duyusunun ve algısının oluşumunda önemli bir alanı kapsamaktadır. İnsan, renk aracılığıyla yaşam çevresini anlamlandırmakta ve görme eylemi renkle birlikte bir anlam boyutu kazanmaktadır. Renk kavramının insan etkileşimli yapısı, renklerin fiziksel, psikolojik ve sosyolojik bağlamda farklılıklar göstermesine yol açmaktadır. Bu farklılıklar ise renklere anlam ve temsiliyet yükleyerek bir ifade gücü ortaya çıkarmaktadır. Renklerin ifade gücü, birçok tasarım ve sanat alanında etkili bir enstrüman olarak kullanılmaktadır. Sinema disiplininde de yönetmenler, anlatım dili oluşturmada renklerden yararlanmaktadır. Sinemada konunun belirlenen süre içindeki anlatımı, mekânsal renk kullanımıyla desteklenmekte ve anlatım dilinin etkisi artırılmaktadır. Böylece sinemekânlar tasarlanırken seçilen renk türleri, yönetmenlerin bilinçli tercihi sonucunda ortaya çıkmaktadır. Sinemada renk kullanımının mekân ve anlatım ilişkisi ekseninde incelenmesi iç mekân tasarımcıları için de yeni bir veri oluşturmaktadır.

Görsel duyunun ve algının temel ögelerinden biri olan renk, nesneler tarafından yansıtılan ve soğurulan ışığın, göz aracılığıyla beyinde oluşturduğu her bir etkidir. Rengin insanın yaşam çevresinin şekillenmesinde ve anlamlandırılmasında büyük bir rolü vardır. İnsan, nesneleri rengin ayırt edici niteliği sayesinde duyumsamaktadır.

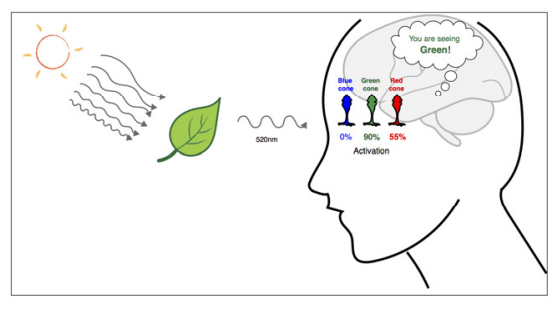

Şekil 1: Rengi Görme (URL1).

Renk, esas olarak fizyolojik bir unsur olan ışığın uzantısıdır. Nesnenin yansıttığı ve absorbe ettiği ışık dalga boylarının kavranma niteliğidir. Bu sebeple, rengin mutlak varlığı ışığa bağlıdır. Işığın olmadığı bir ortamda rengin var olması mümkün değildir. Renk ve ışığın doğrudan ilişkisi, tarihte ilk kez Newton tarafından incelenmiştir. Newton, rengin ışığın bir türevi olduğu teorisini ortaya koymuştur. Karanlık bir odaya küçük bir aralıktan ışık demeti sızdırdığı deneyinde, ışığı cam bir prizmadan geçirmiş, daha sonradan "güneş tayfı renkleri" olarak adlandıracağı renklere ayırmıştır. Işığın farklı dalga boylarında kırmızı, turuncu, sarı, yeşil, mavi, indigo ve mor olmak üzere yedi renge ayrıştığını ve tüm bu renklerden beyaz ışığın ortaya çıktığını kanıtlamıştır. Beyaz ışığın yedi renge ayrılması, ışınların farklı dalga boylarından oluşması ve prizmadan geçerken farklı oranda kırımalarından kaynaklanmaktadır (Özdemir, 2005, s.3-4).

\section{RENGIN ANLAM VE TEMSILIYYETI}

İnsan gözü, yapısı gereği milyonlarca rengi duyumsayabilecek şekilde gelişmiştir. Gözün retina tabakasında yer alan "koni hücreleri"nin yoğunluğu ve dağılımı her insanda biyolojik nüanslar göstermektedir. Bu sebeple renklerin duyumsanması kişiden kişiye değişebilmekte ve renkler farklı biçimlerde algılanabilmektedir.

Renk algısındaki değişkenlik, salt biyolojik sebeplerden kaynaklanmamaktadır. Renk algısı, fiziksel ortamda başlayıp beyinde sonlanan bir süreç sonucunda ortaya çıkmaktadır. Böylece beyin de renklerin farklı algılanmasında rol oynamaktadır. Rimington (1912) renk algısının insan beynindeki etkileşimini şöyle açıklamaktadır: "Renk, insanın hayal gücünü etkileşime sokar ve zihinsel güçlerini etkiler. Zihinde tatmin ve canlanma 
duygusu oluştururken, etkilemeyi başardığı duyuların reaksiyonlarını arttırır." (Rimington, 1912, s.16). Beynin bir anlam oluşturmak için renkleri yorumlama şekli kişiler arasında değişiklikler gösterebilmektedir. Yani renk, beyinde oluşan görüntü sonucu şekillenmekte ve renk algısı öznel olmaktadır. Bu bağlamda, rengin kendine özgü bir anlam ve temsiliyet gücünün olduğu söylenebilmektedir.

Renk algısının öznel niteliği ve zihinde yarattığı etki, sinema sanatında anlatım dili oluşturmada başvurulan bir yöntem olarak öne çıkmaktadır. Yönetmenler, renk kullanımıyla sinemanın anlatım gücünü desteklemekte ve izleyiciye daha etkili biçimde sunmaktadırlar.

\section{SINEMEKANLARDA RENK KULLANIMI}

Sinema tarihinde renk kavramının bir yöntem olarak kullanılması 20. yüzyııı başlarına kadar uzanmaktadır. Sinemanın renk öncesi dönemlerinde siyah ve beyazın tonları kullanılarak renk armonisi yaratılmaya çalışımıştır. Renk kullanımının başladığı ilk dönemlerde ise rengin kullanımı yalnızca öz niteliklerinden yararlanma amaçlı olmuştur. Sinema sanatının tarihsel süreç içindeki gelişimiyle birlikte renkler, bir anlatım aracı olarak kullanılmaya başlanmış ve sanatsal bir ifade biçimine dönüşmüştür. Türk sinema kuramcısı Alim Şerif Onaran (1986, s.46) sinemada renk kullanımının gelişimini dört bölümde incelemiştir. Bunlar "Resimsel Renk, Tarihsel Renk, Sembolik Renk ve Psikolojik Renk" tir. Resimsel renk, renklerin bir tablo yaklaşımıyla resimsel kompozisyon oluşturacak biçimde lekesel kullanımıyken, tarihsel renk kullanımı bir dönem içinden seçilen renklerin kullanımını tarif etmektedir. Sembolik renk, renklerin temsiliyet gücünden yararlanılarak sembolik amaçla kullanımıdır. Psikolojik renk ise, renklerin insanlar üzerinde yarattığı psiko-etkiler doğrultusunda kullanılma biçimidir.

Sinemada renk kullanım yöntemi ve renk-anlatım ilişkisi bağlamında önde gelen yönetmenlerden biri Wes Anderson'dır. Gerçek adı Wesley Wales Anderson olan yönetmen Amerika Birleşik Devletleri'nde, 1969 yılında doğmuştur. Wes Anderson, renk kullanımı ve oluşturduğu renk skalalarıyla zengin bir anlatım dili yaratmış, özgün kimliğiyle sinema tarihinde yer edinmiştir. Bu çalışmada, Wes Anderson sinemekânlarının renk-mekân-anlatım ilişkisi, ilk "sinema profesörü" olarak anılan Alim Şerif Onaran'ın sinemada renk kullanımını incelediği parametrelerden yola çıkılarak incelenmektedir.

\subsection{Renk, mekân ve anlatım dili ilişsisinde wes anderson}

Çağdaş sinema tarihinin önemli isimlerinden Wes Anderson, kendine özgü üslubu ve anlatımı ile eleştirmenlerce "auteur" olarak nitelendirilmiştir. "Auteur" veya "otör" kelimesi etimolojik olarak Fransızca "auteur" kelimesinden gelmekte ve "Film Yaratıcısı, Yaratıcı" anlamını taşımaktadır. Sinema Terimleri Sözlüğü’nde (1963) "auteur" kavramı "Bir filmin konusundan kurgusuna kadar bütün çalışmalardan doğrudan doğruya sorumlu bulunan, filme kendi deyişini veren, damgasını vuran sinema sanatçısı" şeklinde ifade edilmektedir. Dolayısıyla yönetmenin filmine, işaretini veya imzasını anlatım dili ile koymasıdır. Filmin yaratımındaki kolektif karar sürecine rağmen yönetmenin yaratıcı sinema dili, auetur yönetmenlerin filmlerinde daha belirgindir. Dolayısıyla yönetmenin eserleri kendi adıyla özdeşleşir, anılır. Auteur yönetmenin özgün dili ve bıraktığı iz, filmin yönetmeni bilinmese de fark edilebilecek boyuttadır.

Auteur sözü ilk olarak 1950'li yıllarda André Bazin tarafından Cahiers du cinema (Sinema Defterleri) isimli Fransız sinema dergisinde kullanıldı (URL 2). Auteur Teoriye göre film, yönetmenin dünya görüşünü ve evrensel boyutta "insan" olma özelliğininin yanı sıra sanatçı kimliğini de aktarabileceği bir eserdir. Bu bağlamda Wes Anderson, filmlerinde kullandığı teknikler, içsel anlamlar ve özgün üslubuyla auteur bir yönetmendir. 
Anderson'ı auteur bir yönetmen yapan ve filmlerini ortak bir noktada birleştiren özellikleri; kullandığı çekim teknikleri, görsel metinler, müzikler ve renk skalalarıyla şekillendirdiği estetik anlayışıdır. Wes Anderson'ın, sahnelerde kompozisyon oluştururken başvurduğu çekim teknikleri "Wes Anderson Sinememasında Bakışın Etkin Kullanımı" (URL 3) adlı çalışmada irdelenmektedir. Bunlar "P.O.V shot" (bakış açısı çekim) ve "Bird's-eye Shot" (kuş bakışı çekim) teknikleridir. "P.O.V shot", izleyicinin karekterle bütün oluşturduğu bir çekim tekniğidir. Bu teknikte duyguyu yaşayan karakter ve izleyicinin bütünleşmesi ve izleyicinin karakter gözünden sahneyi yaşaması hedeflenir. "Bird's-eye Shot" ise kuş bakışı açısıyla izleyicinin karakterin göremediği şeyleri de görebildiği bir çekim tekniğidir.

Wes Anderson, kompozisyonlarında simetriyi sıklıkla kullanmaktadır. Simetrik kompozisyonlarda karakter veya nesne, büyük bir özenle kadrajın tam ortasına yerleştirilmekte ve kadraj doğrudan ikiye bölünmektedir. Simetri, Anderson filmlerinde en karakteristik unsurlardan biridir. Wes Anderson filmlerinde bir diğer estetik unsur müziktir. Anderson'ın, filmlerinin temalarına uygun müzik kullanımındaki ustalığı, atmosfer yaratma ve kurgunun anlatımında önemli bir yer tutmaktadır. Wes Anderson'ın auteur kimliğini oluşturan en önemli öğe ise filmlerinde kullandığı renklerdir. Renk skalaları, Anderson'ın filmlerinde yaratmak istediği büyülü gerçekçi etkiyi izleyicilere aktarmada bir yöntem olarak kullanılır. Büyülü gerçekçi etkide, gerçek ve gerçeküstünün birleşiminden yararlanılır; mucizeler ve olağanüstü olaylar sıradan bir anlatıyla sunulur. Wes Anderson, set tasarımlarında aksesuardan kostüme kadar her alanda yarattığı özgün renk skalalarıyla büyülü gerçekçi bir etki yaratır. Zeiss (2013) "The Wes Anderson Collection" adlı kitabında, Anderson'ın sinemekânlarını "oyuncak bebek evi estetiği" (dollhouse aesthetic) olarak tanımladığını belirtmektedir.

Anderson sinemekânlarında renkleri çoğu zaman karaktere kontrast olacak şekilde kullanır ve böylece karakteri ön plana çıkarır. Anderson'ın renk skalalarında yoğun bir biçimde sarı renk ve tonlarının kullanımı dikkat çeker. Sarı renk yoğunluğu, sahnede dikkat çekmek istediği unsurları vurgulamak için kullandığı etkili bir yöntem olarak düşünülür (Dilley, 2012). Sarı renk, anlatı ortamında alanca lekesellik yaratmak için güçlü bir renktir. Anlatı ortamında, renk ile objeler arasında kurulan bağ, seyircinin sinemekânı algılamasında önemli bir etmendir. Anderson renk skalalarında sıklıkla vurgulanan bir diğer renk ise kırmızıdır. Kırmızı rengin pastel tonların önünde kullanılarak çarpıcı bir parlaklıkla algılanan estetik değeri, izleyicinin dikkatini çeker, bir heyecan hissiyatı veya arzu duygusu uyandırır. Şekil 2'de Anderson'ın filmografisinden seçilen sahnelerde sarı ve kırmızı renklerin kullanımı gösterilmektedir. 


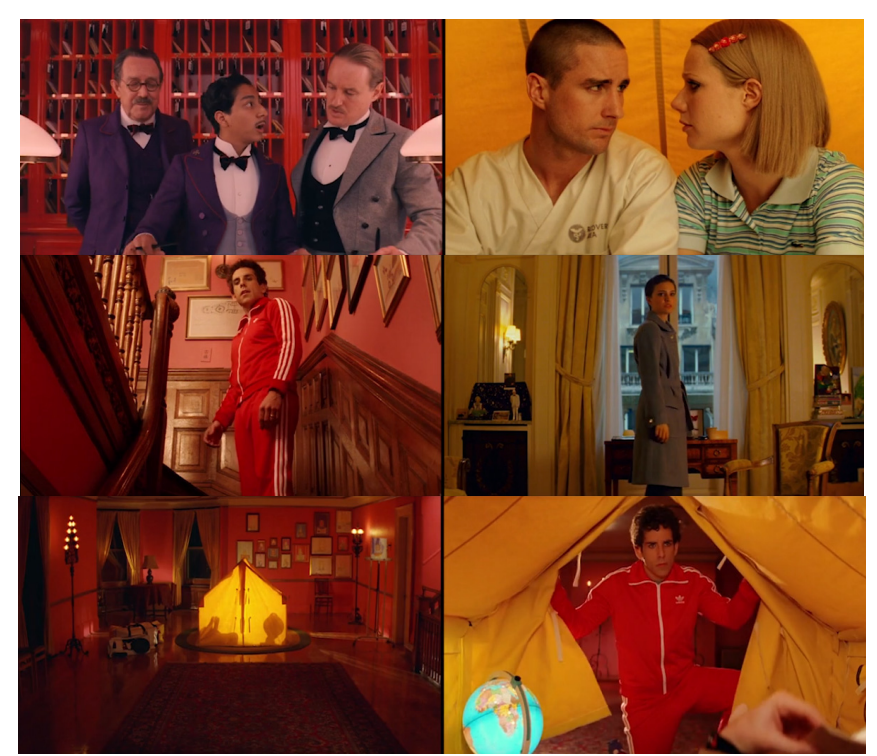

Şekil 2: Anderson'ın Sinemekânlarında Kırmızı ve Sarı Renk Kullanımı (URL4).

Vreeland'in aktarımına göre (2015), Anderson sinemekânlarının yaratım süreci, yapım tasarımcısı Adam Stockhausen'le belirledikleri renk skalalarıyla başlar. Renk skalaları ile bağdaşan belirli objelerin izleyicide etki yaratacak biçimde mekânlara yerleştirilmesi de sürecin bir parçası olur. Şekil 3'te Wes Anderson sinemekânlarından renk ve detay örnekleri sunulmaktadır. Renk ve detay için gösterilen bu özen bazen tek rengin bir objede kullanılarak vurgulanmasıyla olabileceği gibi bir veya birden çok rengin alanca baskın kullanımı olarak mekâna yansımaktadır. Dolayısıyla rengin, Anderson sinemekânlarında anlatımı güçlendiren dominant bir öge olduğu söylenebilir. Anderson'un ışık ve renkleri, karakterler ve diğer objeler ile birlikte etkileşime girdiğinde, anlamsal bir bütünlük sağlanır. İzleyiciler, film içerisinde kullanılan birçok farklı renk değerini algılar ve bu algılar onları belirli bir odak noktası veya tema üzerine yoğunlaştırmaya katkı sağlayarak anlatımı güçlendirir.

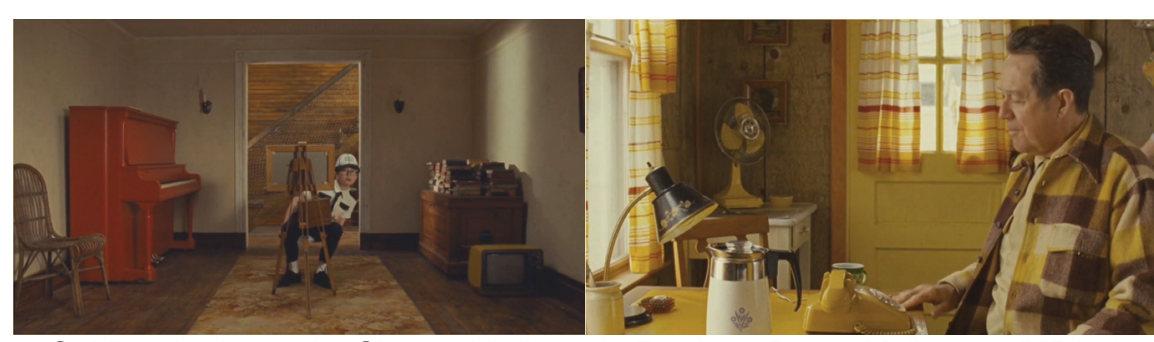

Şekil 3: Anderson'ın Sinemekânlarında Renk ve Detay Kullanımı (URL5).

Wes Anderson, filmlerinde özünde birbirine benzeyen temaları işler. Filmlerin büyük çoğunluğunda odak noktası ebeveynler ve onların çocukları ile olan ilişkilerdir. Anderson'un filmleri, auteur yönetmen kimliği göz önünde bulundurulduğunda, renk ve anlatım ilişkisine getirdiği öz-bilinçsel yaklaşım öne çıkar. Anderson, filmlerinde renklere kendi perspektifinden bakarak mekânları tasarlar ve izleyiciye sunar. Anderson'ın mekânları kendi çocukluğunun bir yansıması olarak kabul edilir (Mayshark, 2007, s.116). Anderson'ın sinemekân tasarımlarında 1970'li yılların estetik anlayışından etkilere sıklıkla rastlanır ve dönemin renklerinin yoğun kullanımı bunu destekler. Anderson, günümüz karmaşık dönemini, geçmişte var olduğunu ve insanların merkezini oluşturduğunu düşündüğü kibarlık, saygı, dürüstlük gibi değerlerle doldurmak ister. Bu nedenle, filmlerindeki nostaljik ögeler ve renkler geçmişe duyduğu özlemle ilişkilendirilebilmektedir. 


\subsection{Sinemekânsal renk incelemeleri}

Wes Anderson sinemekânlarında renk-mekân ve anlatım dili ilişkisi, "Tenenbaum Ailesi", "Küs Kardeşler Limited Şirketi" ve "Büyük Budapeşte Oteli" filmlerinden seçilen sinemekanlarla analiz edilmektedir. Sinemekânlar, Onaran'ın sinemada renk kullanımını incelediği parametrelerden yola çıkılarak psikolojik, resimsel, sembolik ve tarihsel renk kullanımları doğrultusunda incelenmektedir.

\subsubsection{Wes Anderson sinemekânlarında psikolojik parametre olarak renk kullanımı}

Tablo 1, Tablo 2 ve Tablo 3'te Wes Anderson sinemekânlarında, psikolojik parametre olarak renk kullanımı incelenmektedir. Sinemekânların renk incelemesinde, rengin tür, ton, doymuşluk ve armoni niteliklerinden yararlanılmaktadır. Seçilen sinemekânlardaki renk kullanımları, ilgili sahnelerin psikolojik anlatımıyla ilişkilendirilmektedir.

Tablo 1: Wes Anderson Sinemekânlarında Psikolojik Parametre Olarak Renk Kullanımı

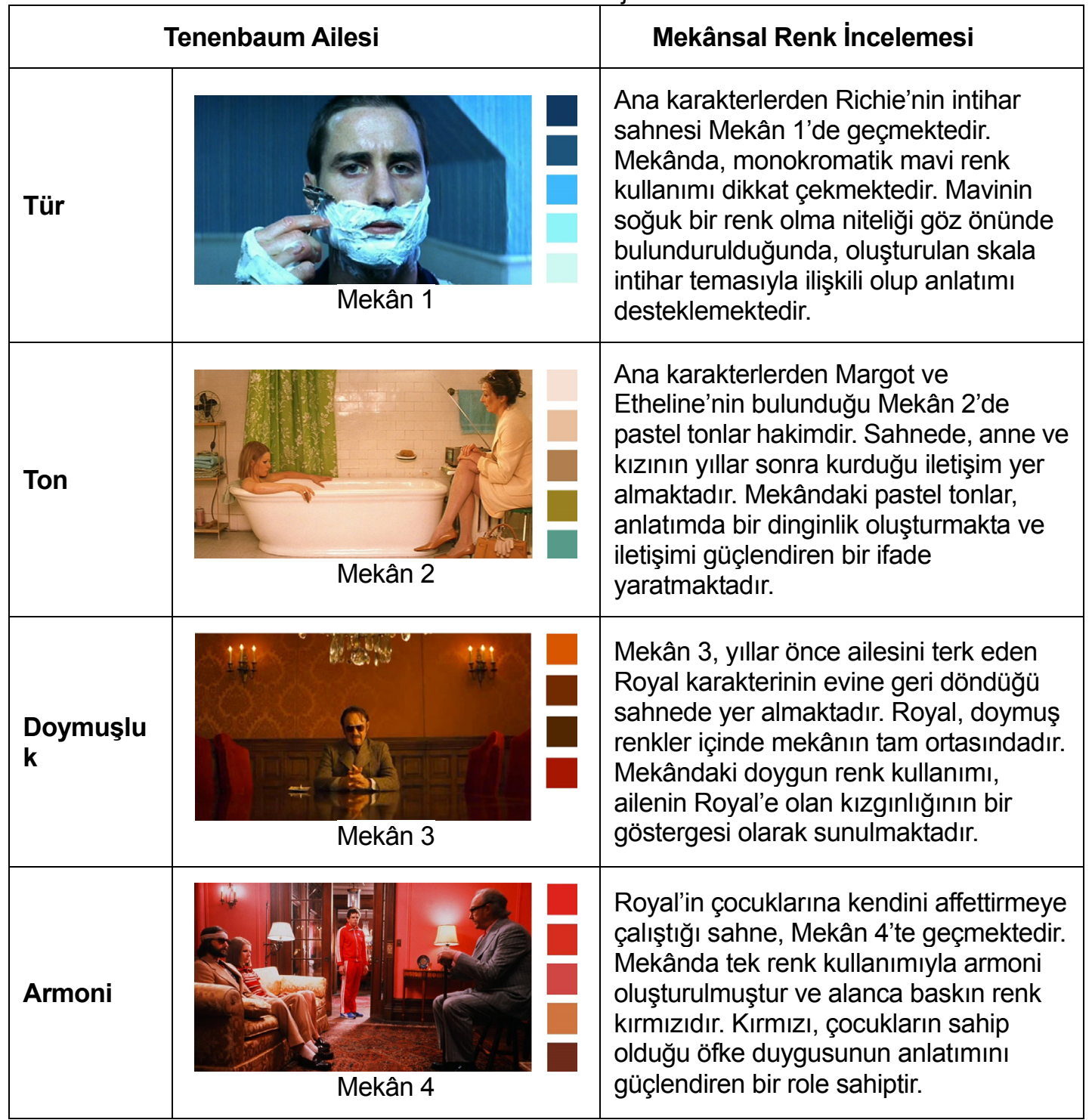


Tablo 2: Wes Anderson Sinemekânlarında Psikolojik Parametre Olarak Renk Kullanımı

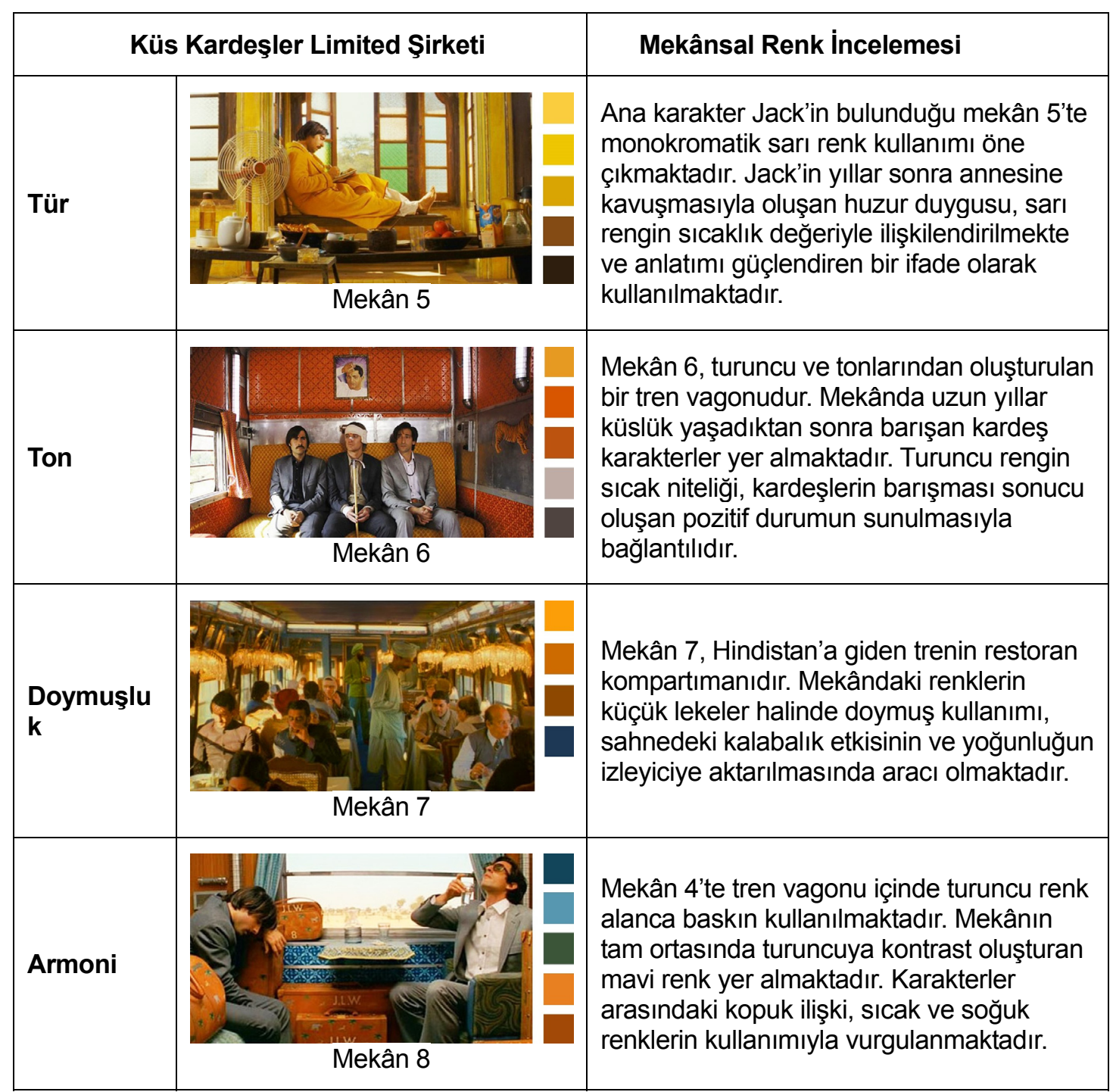


Tablo 3: Wes Anderson Sinemekânlarında Psikolojik Parametre Olarak Renk Kullanımı

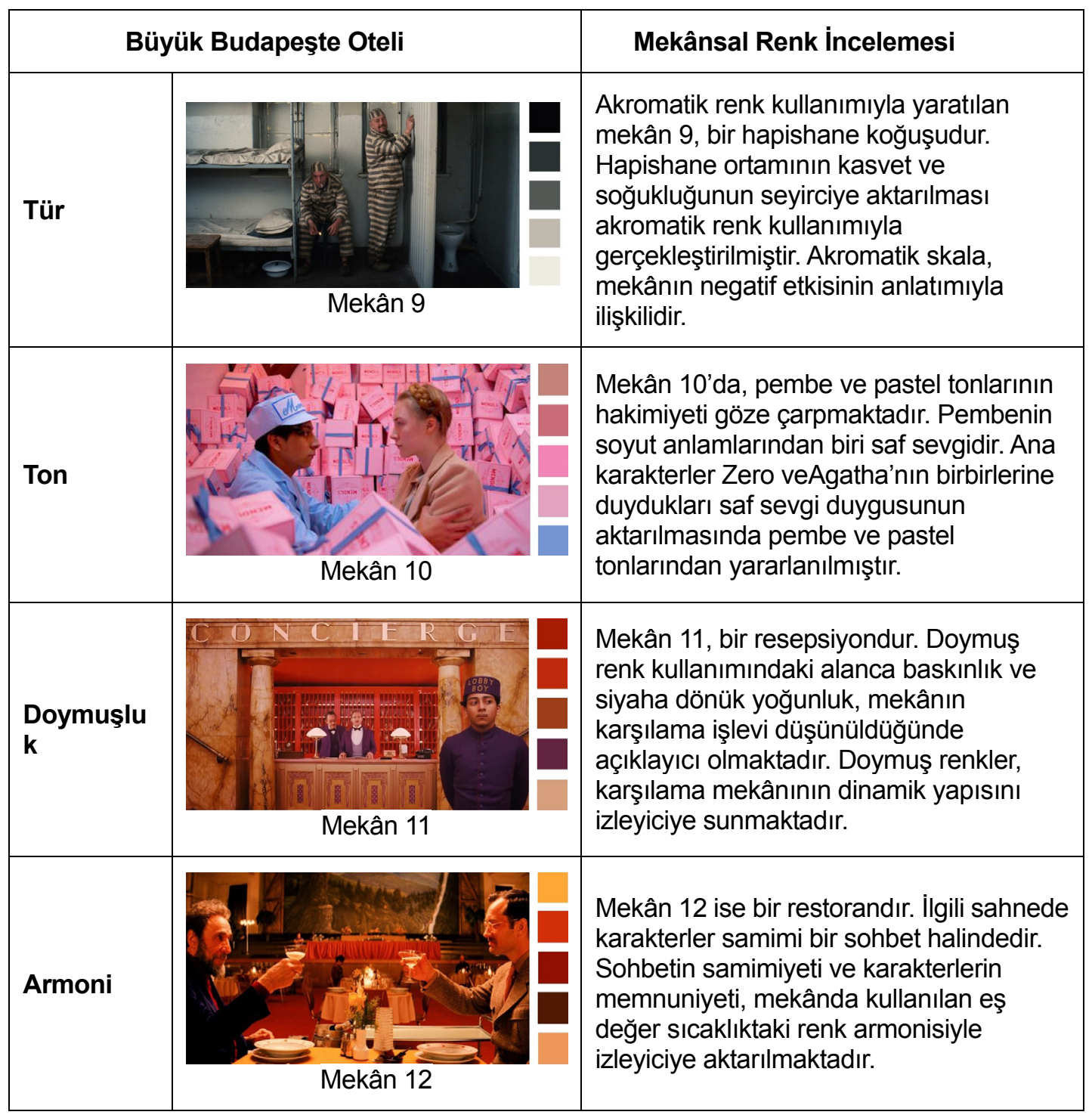




\subsubsection{Wes Anderson sinemekânlarında resimsel, sembolik ve tarihsel parametreler olarak renk kullanımı}

Tablo 4, Tablo 5 ve Tablo 6'da Wes Anderson sinemekânlarında, resimsel, sembolik ve tarihsel parametre olarak renk kullanımı incelenmektedir. Seçilen sinemekânlardaki renk kullanımları, ilgili sahnelerin anlatımsal niteliğiyle ilişkilendirilmektedir.

Tablo 4: Anderson Sinemekânlarında Resimsel, Sembolik ve Tarihsel Renk Kullanımı

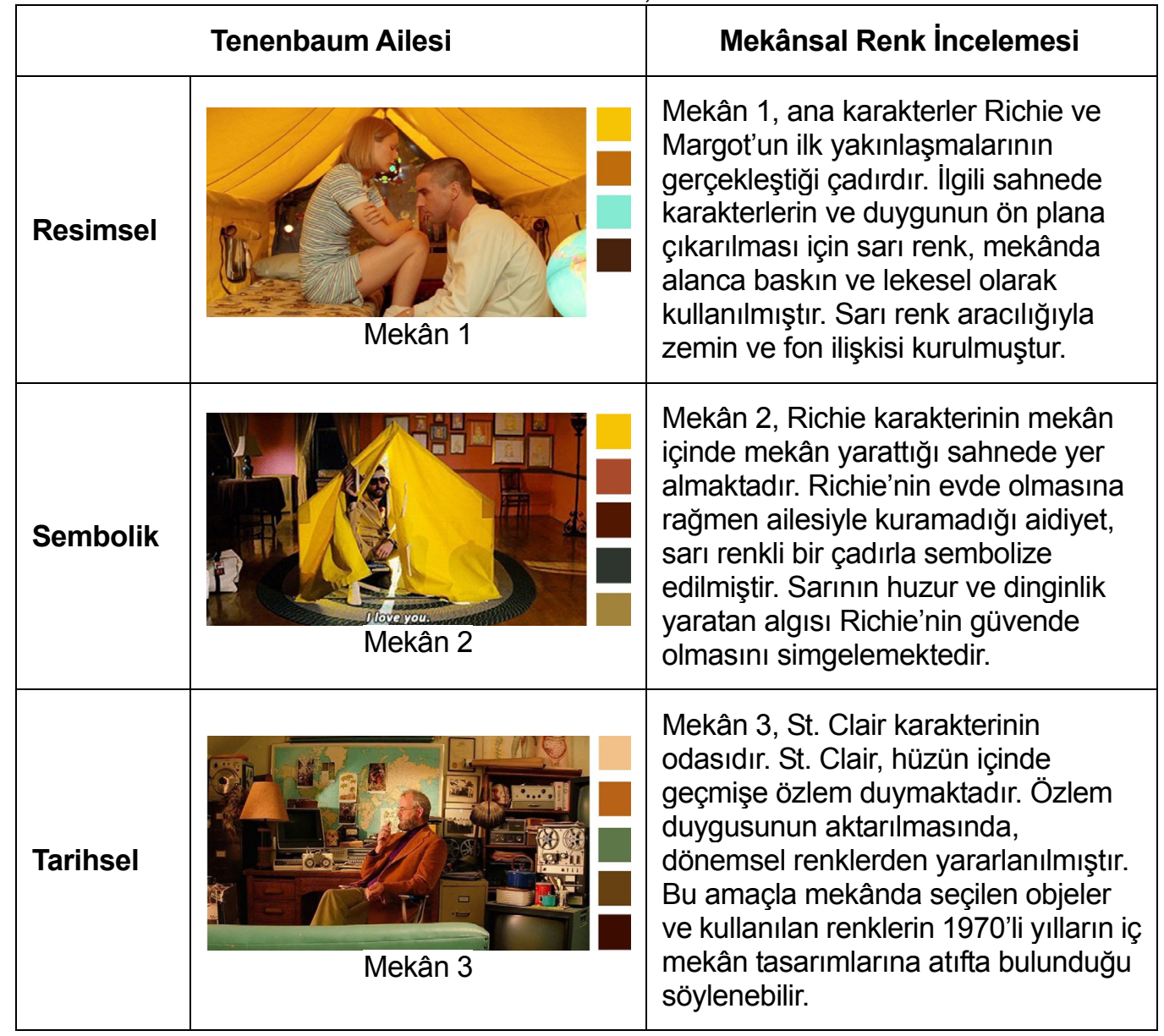


Tablo 5: Anderson Sinemekânlarında Resimsel, Sembolik ve Tarihsel Renk Kullanımı

\begin{tabular}{|l|l|l|}
\hline \multicolumn{2}{|c|}{ Küs Kardeşler Limited Şirketi } & \multicolumn{1}{c|}{ Mekânsal Renk İncelemesi } \\
\hline Resimsel & $\begin{array}{l}\text { Mekân 4'te ana karakterlerden Peter, } \\
\text { baba olacağı bir dönemde, başka bir } \\
\text { babanın evladını kaybetmesine tanıklık } \\
\text { etmiştir. Mekânda mavi renk, figür } \\
\text { olarak Peter'in öne çıkmasını } \\
\text { sağlamak ve duygu durumunu ön } \\
\text { plana çıkarmak amacılyla alanca } \\
\text { baskın kullanılmıştır. }\end{array}$ \\
\hline Sembolik & $\begin{array}{l}\text { Mekân 5, bir oto tamir mekanıdır. } \\
\text { Mekândaki araba, üç kardeşin } \\
\text { yaşamını yitiren babalarına aittir. Olay } \\
\text { örgüsü bağlamında kardeşlerin oto } \\
\text { tamircisine gidip arabayı çalıştırma } \\
\text { girşimleri, babalarını hayata döndürme } \\
\text { isteklerini simgelemektedir. Turuncu } \\
\text { araba ise dinamizm yaratmakta, } \\
\text { yaşamı sembolleştirmektedir. }\end{array}$ \\
\hline Tarihsel & $\begin{array}{l}\text { Mekân 5, eski bir kiliseye aittir ve Peter } \\
\text { mekân içinde ibadet etmektedir. } \\
\text { Mekânda yer alan yüzey renklerinin } \\
\text { yenilenmeden geçmişe ait izleriyle } \\
\text { birlikte kullanımının tarihsel bir anlatım } \\
\text { yarattığı söylenebilir. }\end{array}$ \\
\hline
\end{tabular}

Tablo 6: Anderson Sinemekânlarında Resimsel, Sembolik ve Tarihsel Renk Kullanımı

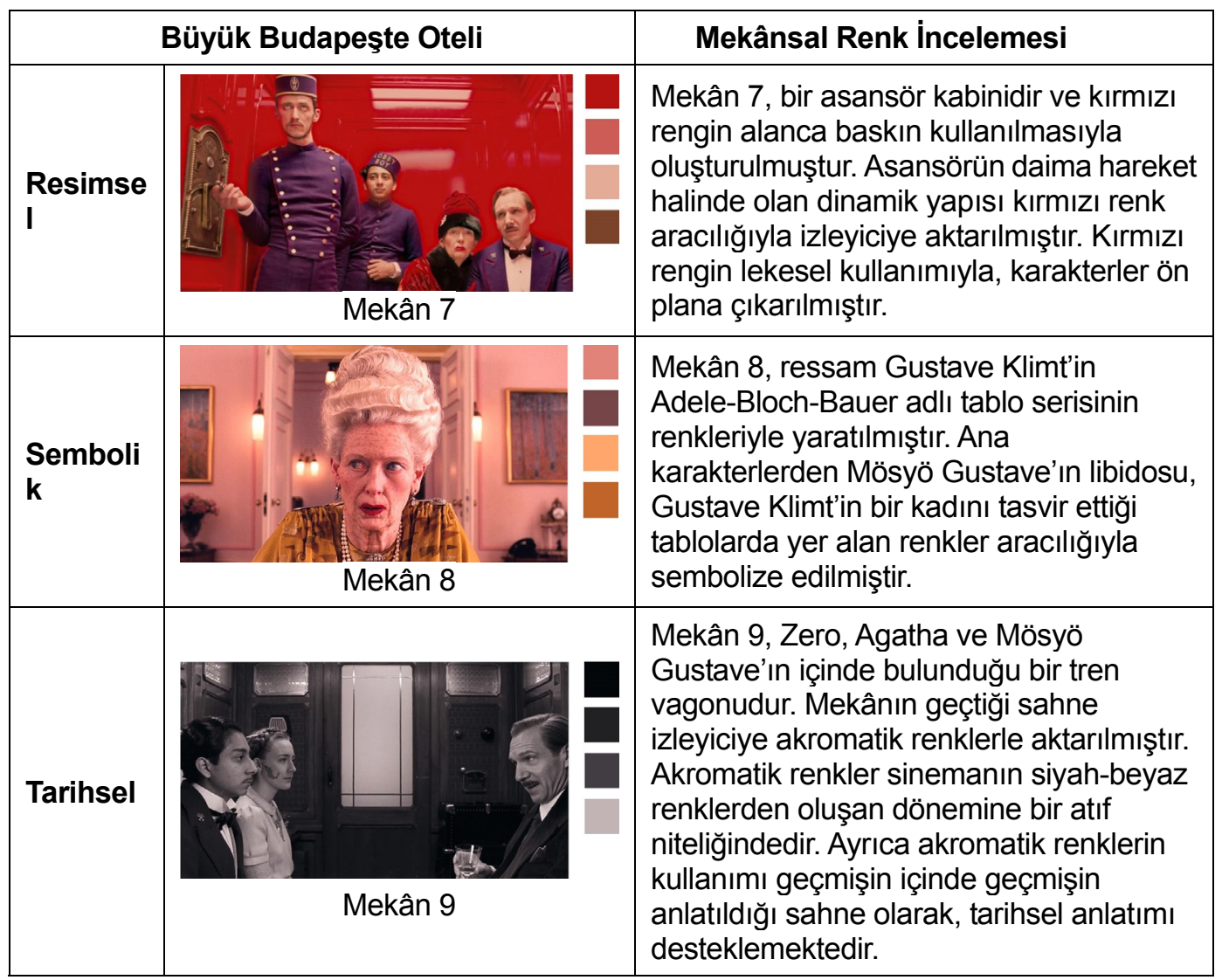




\section{DEĞERLENDIRME ve SONUÇ}

Renk, insan algısındaki anlam ve temsiliyet gücüyle sinema sanatında efektif bir araç haline gelmiştir. Yönetmenler, rengin insan üzerindeki kavramsal etkisinden yararlanarak sinemekânlarını kurgulamış, sinemanın sınırlandırıımış zaman dilimindeki anlatımını güçlendirmiştir. Renk, mekân ve anlatım ilişkisinin Wes Anderson sinemekânları üzerinden irdelendiği çalışmanın sonucunda, renk kavramının kurgusal mekânların tasarımındaki kullanım amaçları ve yöntemleri analiz edilmiştir. Wes Anderson, rengin niteliklerini, kendine özgü algılayış biçimiyle yorumlayarak sinemada bir anlatım dili yaratmıştır. Anderson'ın sinemekânlarında kullandığı renkler, karakterlerin duygu durumlarının anlatımını güçlendirmiş ve izleyiciye aktarımını etkili biçimde gerçekleştirmiştir. Wes Anderson sinemekânlarını tasarlarken renklerin teknik özelliklerinden de yararlanmıştır. Renklerin lekesel-alansal kullanımı ve figür-zemin ilişkisinin kurgulanmasıyla, izleyicinin belirli bir odak noktası veya tema üzerine yoğunlaşması sağlanmaya çalışılmıştır. Bunların yansıra, sembolik ve tarihsel renk kullanımlarının anlatımı güçlendiren bir yöntem olarak sinemekânlarda kurgulandığı da söylenebilmektedir.

Rengin niteliklerinden yararlanılarak oluşturulan bir sinemekânın irdelenmesiyle, renk psikolojisiyle ilgili verilere ulaşılabilmekte ve rengin resimsel, sembolik ve tarihsel kullanımıyla ortaya konan mekân örnekleri renk - mekân- anlatım dili arasındaki güçlü ilişkiyi ortaya koymaktadır. Sinema sanatının mekânsallığı göz önünde bulundurulduğunda, Anderson'ın sinemekân tasarımlarında kullandığı renk skalaları, rengi kullanma biçimleri ve rengin sembolik anlamlarının kurgusunun, iç mekân tasarımcılarına atmosfer oluşturmada bir veri niteliği taşıdığı söylenebilir. Rengin iç mekân tasarımı dışındaki bir disiplinde kullanımının incelenmesi, tasarımcılara referans oluşturacak yeni bir bakış açısı geliştirmeye olanak sağlamaktadır.

\section{KAYNAKLAR}

Dilley, Whitney Crothers. Wes Anderson: Bringing Nostalgia to Life, Wallflower Press, 2017

Mayshark, Jesse Fox, Post-Pop Cinema: The Search for Meaning in New American Film, Abc-Clio Information Services 2007, s.116-117

Onaran, Alim Şerif, Sinemaya Giriş, Agora Kitaplığı, İstanbul 1986, s.46

Özdemir, Tülay, Renk Kavramı ve Konut İç Mekânında Tasarıma Etkileri, Mimar Sinan Güzel Sanatlar Üniversitesi, Fen Bilimleri Enstitüsü, İstanbul 2005, s.3-4

Rimington, Alexander Wallace, Color-Music, e-book, 1912, s.16

Özön, Nejat, Sinema Terimleri Sözlüğü, Türk Dil Kurumları Yayınları, İstanbul 1963, s.46

Vreeland, Vaughen, Color Theory and Social Structure in the Films of Wes Anderson, Elon Journal of Undergraduate Research in Communication, Vol.6, No.2, Fall 2015, 2015, s.36

Seitz, Matt Zoller, The Wes Anderson Collection, Abrams Books, 2013, s. 152

URL1.http://sitn.hms.harvard.edu/flash/2015/from-kansas-to-oz-how-new-glasses-coul d-change-the-way-the-colorblind-see-the-world/ (Erişim Tarihi:10.8.2019) 
URL 2. https://sinemaseyirdefteri.wordpress.com/2015/01/23/auteur-teorisi/ (Erişim Tarihi:15.10.2019)

URL 3. https://www.filmloverss.com/wes-anderson-sinemasinda-bakisin-etkin-kullanimi/ (Erişim Tarihi:10.8.2019)

URL 4. https://vimeo.com/120325993 (Erişim Tarihi:15.6.2019)

URL 5. https://vimeo.com/182987900 (Erişim Tarihi:15.6.2019) 